\title{
Multilingual Texts as a Reflection of Code-Switching in Medieval England: Sermons and Beyond
}

\section{Herbert Schendl*}

The multilingualism of medieval England especially in the Middle English period, has for long been the subject of research in historical linguistics, literature, and medieval studies, to name but a few. It is particularly visible in the monolingual texts in the different medieval languages of literacy (Latin and Old English in the Old English period, and French, Latin and English in the Middle English period), where it has left traces in the lexicon and grammar of English.

More recently, the numerous multilingual texts from medieval England have attracted increased attention, not least because they can be seen as written evidence for code-switching, a well-known discourse strategy in multilingual societies. Multilingual sermons are among the best-known text types showing this mixing of languages, and they are found from the Old English period onwards, though they are particularly well attested from the later Middle English period.

The present paper will look at the main types of multilingual sermons from medieval England, both from the Old English and the Middle English periods. It will, however, go beyond this and place such sermons in the context of other medieval multilingual text types. Based on the analysis of a range of medieval multilingual texts, we will show that multilingual sermons, especially the so-called "macaronic sermons «, are not as unique as sometimes claimed in sermon studies. After a critical discussion of the traditional criteria for defining "macaronic" texts, we will argue that such texts can be better accounted for on the basis of functional classifications as provided by modern code-switching theories. Such an approach in no way reduces the special nature of "macaronic sermons«, but it firmly places them in the wider bilingual context of medieval England and the multilingual strategies regularly used by its speakers and writers in a variety of text types. The contextualisation of multilingual sermons in this wider context of written multilingual texts will hopefully lead to a better understanding of multilingual sermons from medieval England and possibly also those from other European countries.

Keywords: multilingualism; language mixing; code-switching; medieval period; England; Latin; English; text-types; sermons; administrative texts; literature

\footnotetext{
* Correspondence details: Herbert Schendl, Institut für Anglistik und Amerikanistik, Universität Wien, Spitalgasse 2, 1090 Vienna, Austria; herbert.schendl@univie.ac.at.
} 


\section{Introduction}

Research into medieval sermons has a long history, and the scope of research projects and publications in the field is impressive. Among the topics most studied are the functions, structure, source and content of sermons, their rhetorical form and adherence to the models provided by the handbooks of preaching, the artes praedicandi. Furthermore, their oral delivery by preachers and their transmission in written form, as well as the nature and composition of the intended audience have been discussed. Some of these points have been linked to the increasing use of the vernacular against the predominance of Latin. Multilingual medieval sermons, on the other hand, have attracted much less attention, though there have been some relevant studies for different parts of Europe. ${ }^{1}$

As an historical linguist, my own interests have for a considerable time been in medieval English multilingualism, in particular in the forms and functions of medieval multilingual texts. These I have interpreted as instances of historical written code-switching, and it is code-switching as a written phenomenon which has been my primary object of research, less the recovery of traces of spoken code-switching in such texts. In the last two decades, research in historical code-switching has greatly increased and has established itself as a new sub-field of historical linguistics. Similar to historical pragmatics, historical code-switching research has added a diachronic dimension to a research field which was originally developed for modern spoken languages. Historical multilingual texts should be seen as reflecting similar multilingual communicative strategies as found in modern spoken (but increasingly also written) instances of code-switching - in spite of the obvious differences in the historical context of the two sets of data, i.e. historical and modern.

Code-switching is defined in this paper in a rather wide sense, as the use of two (or more) languages by a multilingual speaker or writer in one communicative event or text. ${ }^{2}$ This definition covers more or less all occurrences of two or more languages within a text, such as single words, phrases, clauses and sentences, paragraphs and inserted verses. Evidently, further subdivisions of these different manifestations of written multilingualism may be necessary or appropriate for specific research questions, such as code-mixing or multilingual practices, and there are a variety of competing terminologies in the field, which cannot be discussed here. ${ }^{3}$ In view of the existing terminological diversity, it seems justified to introduce a few basic concepts of modern code-switching theory which have also proved relevant for historical written data and which will provide the basis for the following discussion.

Code-switching has been studied from a syntactic (or grammatical) perspective and with regard to its pragmatic or sociolinguistic functions. It is this latter, functional aspect which will be the main focus of the present study. ${ }^{4}$ As for the different functions of code-switching, we will follow Peter Auer, who distinguishes between micro-level (or local) functions of code-switching, and macro-level (or global) functions. ${ }^{5}$ On the local level, one can further

\footnotetext{
See, e.g., Bériou, Sermon latins; Kämmerer, Codeswitching in Predigten; Muessig, Vernacularization.

See also Thomason, Language Contact, 132.

See Gardner-Chloros, Code-Switching, 10-13.

For syntactic studies of medieval English code-switching, see Halmari and Regetz, Syntactic aspects; Ingham, Lay subsidy rolls; Schendl, Syntactic constraints.

5 Auer, Codeswitching via language mixing, 310.
} 
differentiate between switches relating to the organisational level of the text (e.g. indication of chapters, argumentative structure of text, types of information, such as report vs. commentary, etc.), and the indexical function of a switch (e.g. expression of authority, of personal involvement, urgency or closeness, etc.). With global functions, on the other hand, it is not the individual code-switch that carries meaning, but the fact of code-switching as such. Such global meanings may be the construction of identity or the expression of specific group membership or ethnicity. Global functions are frequently linked to intrasentential switches, i.e. switches within the clause or sentence.

The present paper will not only look at multilingual sermons from medieval England in general and at the so-called macaronic sermon in particular, but it will place these in the wider synchronic and diachronic context of a range of multilingual text types from that period. Such a contextualisation of multilingual sermons will contribute to a better understanding of a phenomenon which has sometimes been described rather negatively as "linguistically curious «. ${ }^{6}$ However, from such a wider multilingual context, the mixing of languages is a frequent and normal, generally neutral textual strategy found not only in quite a number of medieval texts and text types, but also across cultures and time, in written and spoken communication. Approaching multilingual sermons from a different linguistic perspective does not mean, however, that the highly relevant research in the field carried out by medievalists and theologians will be disregarded, especially research on the most challenging type of multilingual sermon, the so-called macaronic sermon.

\section{Medieval Multilingual Sermons in a Wider Context}

\section{Wenzel's Typology of Macaronic Sermons}

The modern study of multilingual sermons from medieval England is closely linked to Siegfried Wenzel's seminal monograph from $1994,{ }^{7}$ which addresses the topic from a variety of perspectives. In his introductory chapter, Wenzel provides examples of various medieval English verse and prose texts which mix Latin and English to different degrees, all of which he subsumes at first under the traditional term macaronic. According to him, Middle English religious and devotional prose texts generally winclude some Latin words, phrases, or sentences «. ${ }^{8}$ As for Middle English sermons,

it was not only customary but evidently de rigueur to quote authorities in their original Latin [...] Even the most rigorously English sermons have at least one quotation in Latin, their thema [...] It is possible to claim that all Middle English sermons are macaronic. ${ }^{9}$

In a further step Wenzel develops a classification of bilingual sermons based on the nature of inserted elements in relation to the primary language of the sermon, distinguishing three types, namely: 
"a-elements", which »basically translate a part of the Latin discourse or are imported into it in the manner of quotations «, such as "glosses, technical terms, translations of themes and of Latin authorities, and vernacular sayings « $;^{10}$

"b-elements", which are "English words, phrases, clauses, periods, or paragraphs that serve as divisions, subdivisions, or distinctions in the sermon in which they appear «; they "are essential for the structure of scholastic sermons «;

"c-elements«: "here the writer's thought moves forward without glossing, quoting, translating, or announcing a coming development, but it does so in a way that switches back and forth between Latin and English in the middle of sentences. The English material in this passage thus forms syntactically integrated parts of bilingual prose sentences «. ${ }^{12}$

Depending on the occurrence of the different inserted elements, Wenzel distinguishes three types of Latin-English mixed sermons (A, B, C) and two types of English-Latin mixed sermons (D, E). His own study focuses on type $\mathrm{C}$ sermons, which are defined by the presence of $c$-elements (even a single one suffices), though $a$ - and $b$-elements may also occur. In Wenzel's final typology only type $\mathrm{C}$ sermons are called macaronic, which considerably narrows his definition of macaronic. Depending on the number and nature of $c$-elements, a further subdivision into »Minimal $\mathrm{C}$ «, "Marginal $\mathrm{C}$ « and »Full $\mathrm{C}$ « is proposed.

Wenzel's typology has, however, a number of weaknesses. ${ }^{13}$ First of all, he uses different criteria for defining the three types of elements (functional and/or formal); furthermore, $a$-elements in particular form a rather heterogeneous group, with overlaps with some $c$-elements in his later analyses (e.g. in the classification of proverbs and popular sayings); and, most importantly, c-elements are mainly negatively defined. It also remains unclear why the "presence of single words, or phrases of two words of type $c$ « $^{14}$ makes a sermon "Minimal $\mathrm{C}$ «, especially since these two types of $c$-elements are very frequent in type $\mathrm{C}$ sermons (as well as in other historical multilingual text types, see the sections Code-Switching in Old English Texts and Code-Switching in Middle English Texts, and equally in modern spoken code-switching). Wenzel's taxonomy implies the existence of clearly separated types and sub-types of bilingual sermons, but it seems more appropriate to view these as forming a continuum with fuzzy borders. ${ }^{15}$ Last but not least, Wenzel's classification widely disregards $a$ - and $b$-elements, though, from the point of view of code-switching, these are equally important for making a text multilingual.

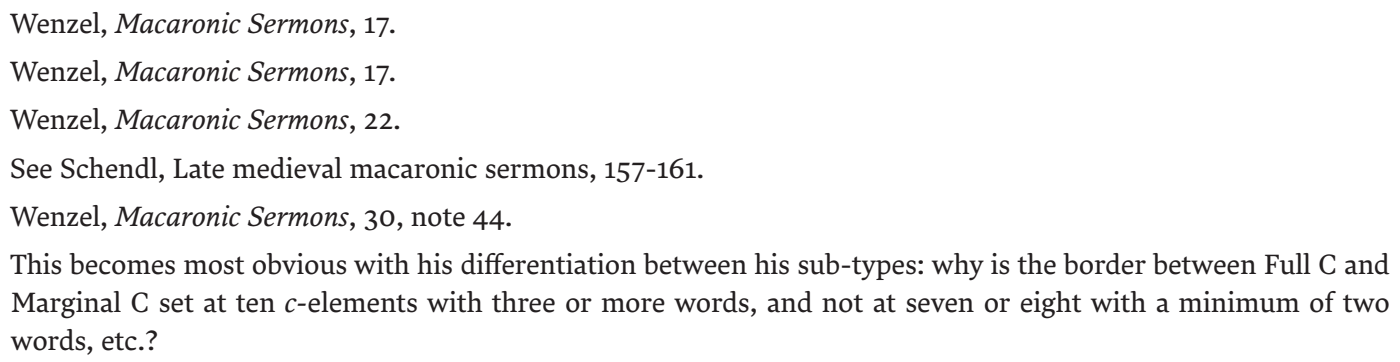
Marginal C set at ten $c$-elements with three or more words, and not at seven or eight with a minimum of two words, etc.? 
If one considers the functions of Wenzel's three types of elements from the point of view of Auer's model, one could say that Wenzel's $a$-elements, though a heterogeneous group, fulfil micro-level indexical functions, his $b$-elements fulfil micro-level organisational functions, while his $c$-elements are intrasentential code-switches with a predominantly macro-level (or global) function, though some may additionally have other functions as well, as Wenzel's own analyses also imply. ${ }^{16}$

A short sample of a fully macaronic sermon from the early fifteenth-century is given under (1): ${ }^{17}$

(1) Quamdiu clerus and pe laife huius terre wer knet togedur in vno fagot and brenden super istum ignem, istud regnum was ful warme and ful wel at hese. Caritas brande so hote, pe ley of loue was so huge quod non Scottich miste ne no Frensche scouris quiuerunt extinguere istam flammam. Set nunc, prodolor, perfectus amor is laid o watur, caritas fere extinguitur, iste ignis is almost out. Quere vbi vis infra villam ex extra, poteris blowe super vngues tuos for any hete of loue. [...] Ex quo igitur confidencia est verum signum amoris, vbi nulla est confidencia ignis amoris is out, pe ignis perfecte caritatis is puffed out.

(As long as the clergy and the laity of this land were knit together in one brand and burned on this fire, this kingdom was very warm and very much at ease. Charity burned so hot, the lay of love was so large that no Scottish mist nor any French showers were able to extinguish this flame. But now, for shame, perfect love is laid to waste, charity is entirely extinguished, this fire is almost out. Seek where you wish within the village or outside, you might [as well] blow on your two fingers for any warmth of love. [...] So, since confidence is a true sign of love, where there is no confidence, the fire of love has gone out, the fire of perfect charity is snuffed out.)

Such a concentration of inserted elements, that is, code-switches into English in a Latin sermon, is, however, rather rare, and passages like the above most often alternate with long stretches of monolingual Latin or with passages containing only few switches. ${ }^{18}$

As mentioned above, Wenzel refers to the existence of other multilingual medieval text types in his introductory chapter, but does not discuss these any further. The following two sub-sections will try to illustrate that the analysis of a variety of multilingual text types can deepen our understanding of "macaronic sermons " by placing them firmly in the overall multilingual text production of medieval England.

17 Videbant signa, Oxford, MS Bodley 649; quoted from Horner, Macaronic Sermon Collection, 221; transl. Horner, 220. In all examples in this paper, code-switches have been marked in italics by the author.

18 See the sermons in Horner, Macaronic Sermon Collection, and Johnson, Grammar of Good Friday. 
Code-switching in Old English texts

Research into historical code-switching has so far rather neglected the Old English period, though there are quite a number of multilingual texts from this period, including sermons of the homiletic type. ${ }^{19} \mathrm{~A}$ recent study of about a quarter of the roughly 270 vernacular homilies from Anglo-Saxon England has briefly analysed the use of Latin material in the Old English texts, in particular those by Ælfric, Wulfstan and the so-called Blickling Homilies, all dating from the tenth century. ${ }^{20}$ Latin code-switches occur in all three collections, though with varying frequency and with more limited patterns than in Middle English sermons. The majority of Latin switches are biblical quotations which are generally supported by a subsequent vernacular translation or paraphrase that is often preceded by a phrase like pæt is (on Englisc) (that is (in English)), so that no Latin competence is expected from audience or readership, see (2). ${ }^{21}$

(2) ealswa hit awriten is \& gefyrn wæs gewitegod: post mille annos soluetur Satanas. Pæt is on Englisc, æfter pusend gearum bið Satanas unbunden. (Whom 5)

(As it is written and was predicted of old: after a thousand years Satan will be unbound. That is in English, after a thousand years Satan will be unbound.)

The Latin quotations are often incomplete, with the omission sometimes being marked by a metalinguistic Latin comment, such as et reliqua (and so forth) for the final part (frequent in Ælfric and Wulfstan), see (3), or usque ad (till, up to) for the middle part (6 instances in the Blickling Homilies), see (4). However, the immediately following Old English translation is generally given in full.

(3)DOMINICA SECVNDA POST PASCA. Ego sum pastor bonus. et reliqua. bis godspel be nu geræd wæs. cwyð pæt se hælend cwæde be him sylfum. Ic eom god hyrde: Se goda hyrde sylð his agen lif for his sceapum. (ÆCHom I, 17)

(Second Sunday after Easter. I am the good shepherd. And so forth. This gospel that has been read now, says that the Saviour said himself. I am the good shepherd: The good shepherd gives his own life for his sheep. Transl. H.S.)

(4) Pa ondswarede he Drihten, [...] \& pus cwæp, Non est uestrum usque ad potestatem ${ }^{22}$; Nis pæt eower, he cwæb, pæt ge witan pa prage \& pa tide ba pe Fæder gesette on his mihte. (Homs 46, BlHom 11)

(Then answered the Lord, [...] and thus spoke, It is not for you up to power. It is not for you, he said, to know the times and the seasons that the Father has put in his power. Transl. H.S.)

19 Exceptions are Schendl, Hec sunt prata; Schendl, Beyond boundaries; Schendl, Code-switching in Anglo-Saxon England; Timofeeva, Anglo-Latin bilingualism.

20 See Schendl, Code-switching in Anglo-Saxon England, 42-46. The study is based on printed editions. On the Old English homily, see Kleist, Old English Homily.

21 References to Old English texts follow the conventions of the Dictionary of Old English Web Corpus (diPaolo Healey, Price Wilkin, Xin Xiang), from which all Old English examples are quoted, with translation by H.S., unless otherwise indicated.

22 The full Latin sentence reads: Non est vestrum nosse tempora vel momenta, quæ Pater posuit in sua potestate. Note the change to the accusative form potestatem which follows the syntax of the metalinguistic comment usque ad. 
Latin biblical quotations like those under (2) to (4) are best explained as having a local indexical function, namely to add authority to the text by using the Latin words of the Bible.

Less frequent in Old English sermons are switches with an organisational function, which help structure the Old English text. In the final part of the Blickling homily on the Assumption of Mary (LS 20, AssumptMor), the beginning of each verse of the Latin Magnificat introduces a vernacular paraphrase or elaboration of the biblical verse. ${ }^{23}$ The first incomplete Latin verse under (5), Fecit potentiam, is syntactically and semantically linked to the following vernacular paraphrase and represents an intersentential switch; the second one, Esurientes, on the other hand, constitutes a single-word switch.

(5) Fecit potentiam, \& he dyde mycle mihte on his <earman>, \& he todælde ealle pa pe pær wæron ofermode on heora heortan, [...]

Esurientes, ${ }^{24}$ \& ba wæs Sancta Maria cwepende pæt Drihten ealle pa gefylde on heofona wuldres fægernesse pa pe hie on eorpan leton hingrian (LS 20, AssumptMar)

(He has shown strength, and he has done mighty things with his arms, and he has scattered all those that were proud in their heart, [...]

The hungry, and then Saint Mary said that the Lord filled all those with the beauty of heaven's glory that on earth had suffered hunger. Transl. H.S.)

Syntactically integrated switched phrases are rather rare in Old English sermons and mostly restricted to titles of books (actus apostolorum), of prayers and songs (pater noster; credo in deum), or religious formulae (patris et filii et spiritus sancti; in modum crucis). There are also a number of Latin single-word switches, mainly religious terms, which are integrated into the vernacular sermon text and generally followed by a translation, such as the seven gifts and the sins of men (sapientia, consilium, etc.; ignorantia, impietas, etc.), the (arch)angels (throni, principatus, etc.), and a few other religious terms such as discipuli and absolutionem.

To sum up, Old English homilies predominantly show a traditional use of switched Latin material, predominantly intersentential switches of biblical quotations followed by vernacular translations, while other forms and functions are less frequent.

Code-switching also occurs in various religious texts from this period, such as a manuscript of the Benedictine Rule, see (6), with a single-word code-switch in the hybrid verb plus noun construction heora confessionem don (make their confession): ${ }^{25}$

(6) Æfter pam Pater noster [...] and æfter pam Credo in deum, [...] pær heora andetnysse don sculon, [...] and swa [...] heora confessionem don, pæt is heora andetnesse. (RegC 1)

(After the Pater noster [...] and after the Credo in deum [...] they shall do their confession, [...] and so [...] make their confession, that is their confession. Transl. H.S.)

23 See Schendl, Code-switching in Anglo-Saxon England, 44.

24 The complete Latin verse reads Esurientes implevit bonis et divites dimisit inanes (The hungry he has filled with good things, and the rich he has sent away empty).

25 For a discussion on why confessionem should be regarded as a code-switch and not as a borrowing, see Schendl, Code-switching in Anglo-Saxon England, 51. It is difficult to assign a clear function to such cases, though it might be an attempt to introduce a technical religious term alongside the existing native form andetnesse. 
An early and linguistically interesting multilingual text type are Old English charters, rather formalised legal documents which record a grant or lease of land and of certain privileges by the king or by high-ranking persons. The royal charter started as a purely Latin document following Roman models, though we find the first instances of code-switching as early as the late seventh century. ${ }^{26}$

The passage under (7) is from an original royal charter from 858. Its introductory part is in Latin, except for personal names and two place names. The specifications of the granted goods and privileges show, however, a number of intrasentential switches of varying length into Old English, all fully integrated into the dominant Latin, while other privileges are in Latin, e.g. XXX. statera kasei et item .X. statera in alia wiwarawic \& .XX. lamba \& .X. fehta (30 weys of cheese, and also 10 weys in the other dairy farm of the people of Wye, and 20 lambs \& 10 fleeces). Here code-switching is neither consistent nor predictable and does not have a purely local function. Thus this bilingual charter would qualify as a »macaronic « text in Wenzel's typology and may be one of the oldest texts of this type from medieval England.

(7) ego EĐELBEARHT rex [...] dabo [...] meo fideli ministro WULLAFE aliquam partem terre [...] hoc est .V. aratra in illa loco ubi WASNGWELLE nominator [...] ab omni servitute regali operis eternaliter liverabo [...] id est an wiwarawic quae ante subjecta erat to wii [...] \& et febresham .I. sealtern \&.II. wena gang mid cyninges wenum to blean Jem wiada \&.IIII. oxnum gers mid cyninges oxnum an wiwarawic .XXX. statera kasei et item .X. statera in alia wiwarawic \&.XX. lamba \& .X. fehta hec autem terra suprascripta et wassingwellan his notissimis terminibus antiquitus circum jacentibus ab occidente cyninges folcland [...] .II.que molina ad illam eandem terram pertinentia [...] hec sunt pascua porcorum quot nostra lingua denbera nominamus [...] Hec sunt prata to wassingwellan stocmed healf be norðan hegforde [...] sue ðer to limpað. (Ch 328 [Birch 496] B 15.1.14)

(I, King Ethelbert [...] give [...] to my faithful thegn Wulflaf some portion of land [...], namely five ploughlands in the place called Wassingwell, [...] I will free [it] eternally from all liability to royal service [...] that is one dairy farm of the people of Wye, which before was subject to Wye [...], and one salthouse at Faversham, and two wagons to go with the king's wagons to Blean wood, and for four oxen pasture with the king's oxen; in the dairy farm of the people of Wye 30 weys of cheese, and also 10 weys in the other dairy farm of the people of Wye, and 20 lambs and 10 fleeces. And the above-written land at Wassingwell [has] from of old these well-known boundaries lying round it: in the west, the king's folkland, [...] and two mills belonging to the same land, [...] These are the swine pastures which we call in our language denbera [...] These are the meadows belonging to Wassingwell: half Stocmead, north of Hegford [...] as belong thereto. Transl. H.S.)

26 For a brief account of the development of Anglo-Saxon charters, see Schendl, Hec sunt prata. 
The next example is from Byrhtferth's Enchiridion, a scientific text which extensively switches between Latin and Old English, in various functions and syntactic forms, from single words, phrases, clauses and sentences up to whole paragraphs. In the following passage, code-switching is used to introduce Latin scientific terminology, that is, for pedagogical purposes. ${ }^{27}$

(8)Lunaris annus byð ælce geare (pæt ys pæs monan ger) [...] and communis (pæt ys gemæne ger) hyt byð hwile on pam oðrum geare [...] On twam wisum ys se dæg gecweden: naturaliter et uulgariter, pæt ys gecyndelice and ceorlice [...] Vulgaris uel artificalis dies est (bæt byð ceorlisc dæg oððe cræftlic) fram pære sunnan anginne pæt heo setle ga [...] Se dæg [...] hæfð syx and hundnigontig punctos. (ByrM 1, Baker/Lapidge)

(Lunaris annus is every year (that is the moon's year) [...] and communis (that is the common year) sometimes comes in the following year [...] In two ways is the day spoken of: naturaliter and uulgariter, that is natural and vulgar [...] (The) vulgaris or artificalis day is (that is the vulgar or artificial day) from the sun's rising until it goes to its seat [...] The day [...] has ninety-six punctos. Transl. Baker/Lapidge)

The pedagogical function of code-switching is even more obvious in Ælfric's Grammar, where it is used to introduce grammatical terms and rules, as in example (9). ${ }^{28}$ This may seem a rather marginal function, but Fletcher has argued for the relevance of similar bilingual grammars from the Middle English period for the development of the "macaronic style in medieval England, especially in sermons. ${ }^{29}$ Though Fletcher's hypothesis may not be convincing, one should be aware that the Middle English grammarians using code-switching consciously or unconsciously followed a method for teaching Latin already used in Anglo-Saxon England.

(9) Đes participivm is ðreora cynna: hic amans uir pes lufienda wer; haec amans femina pis lufiende wif; hoc amans mancipium bes lufienda beowa man; et cetera (Egram B 1.9.1)

(The participle has three genders: hic amans uir, this loving man; haec amans femina, this loving woman; hoc amans mancipium, this loving slave; and so on.)

Though Old English code-switching is predominantly found in non-literary texts, there are also some examples from poetry, where switching seems to mainly fulfil a stylistic function. In the following passage from the Phoenix (Phoen A3.4), the switches occur in every second half-line and are thus linked to the metrical pattern of the poem, with the two languages being fully integrated syntactically and semantically.

27 Inserted single words from a language different from the dominant (or 'matrix') language as found in examples 7, 8, or 16 pose a particular problem in the study of multilingual texts and have been variously analysed as borrowings or code-switches. See the detailed discussion of some Latin forms in Old English texts in Schendl, Code-switching in Anglo-Saxon England, 47-56, including the form punctos in example (8). Following Matras, Language Contact, 110-114, such forms are seen as being placed on a continuum between the two poles, and are best analysed on the basis of a bundle of criteria, which allows for some »fuzzy ground« (Matras, Language Contact, 114).

28 See Timofeeva, Anglo-Latin bilingualism, 19, where the example and translation can be found.

29 Fletcher, Popular Preaching, 57-59. 
(10) Hafað us alyfed lucis auctor pæt we motum her mereri, goddædum begietan gaudia in celo.

((He) has granted us the author of light that we may here merit, with good deeds obtain, the joys in heaven.) (Transl. H.S.)

Code-Switching in Middle English Texts

In the Middle English period (c. 1100/1150 to 1500), code-switching is even more widespread and occurs in a large number of text types, including sermons. ${ }^{30}$ In the twelfth century, a number of homilies adapted from Old English material continue the Old English pattern of code-switching, using Latin biblical quotations with a following translation, with predominantly local function, both organisational and indexical, see the section Code-Switching in Old English Texts. ${ }^{31}$

(11) pe mare to haligen and to wurðien penne dei, pe is icleped sunnedei; for of pam deie ure lauerd seolf seið: dies dominicus est dies leticie et requiei sunnedei is dei of blisse and of alle ireste. non facietur in ea aliquid, nisi deum orare, manducare et bibere cum pace et leticia ne beo in hire naping iwrat bute chirche bisocnie and beode to Criste and eoten and drinken mid griðe and mid gledscipe. ${ }^{32}$

(the more to sanctify and to worship this day which is called Sunday; for of this day our Lord himself says: the day of the Lord is the day of joy and rest, Sunday is the day of joy and of all rest. Nothing is done on this day, except praying to god, eating and drinking with peace and happiness, nothing is done on this day but church attendance and praying to Christ and eating and drinking with peace and happiness.)

Similar switching occurs in some early thirteenth-century Latin-Anglo-Norman bilingual sermons: ${ }^{33}$

(12) Sicume dit l'Evangile Habent Moysen et Prophetas; audiant illos, co est en rumanz "Il unt Moysen et les prophetes; oient ceals«. (Sermon on Joshua)

(As the Gospel says, They have Moses and the prophets; may they hear them, that is in Romance »They have Moses and the prophets; may they hear them.")

In the thirteenth century, the homiletic sermon is increasingly replaced by the emerging scholastic sermon, "in which a theme is announced then systematically divided and developed«, and whose form and structure become increasingly complex..$^{34}$ Till the end of the Middle English period, Latin sermons predominate, and even sermons which were preached in the vernacular were regularly written down in Latin, the prestigious default language of religious texts. Only from "the second half of the fourteenth century do sermon collections

30 See Schendl and Wright, Code-Switching in Early English, 22-23.

31 For the continuation of the Old English homily in the early Middle English period, see Conti, Circulation; Swan, Preaching past the conquest.

32 In diebus dominicis, quoted with translation from Schendl, Late medieval macaronic sermons, 155.

33 See Ingham, Medieval bilingualism, where the example under (12) is quoted with translation, 322.

34 Fletcher, »Benedictus«, 228. See also Johnson, Grammar of Good Friday, xxv-xxviii. 
largely in English begin appearing in any significant quantity «. ${ }^{35}$ Both Latin and English sermons, however, regularly show insertions in the other language, such as the theme of the sermon or inserted verse and quotations, mostly serving an organisational function, that is, providing the structure of the sermon. ${ }^{36}$ See the passage under (13), which shows the only English element in an otherwise Latin sermon: ${ }^{37}$

(13) Que vtilitas in sanguine meo. Psalmo 69. Karissimi, hec verba sic dici possunt: Qwhat profyte is here in myn blode?

(What profit is there in my blood. Psalm 69. Dearly beloved, these words can thus be translated: What profit is there in my blood?)

A bilingual sermon using English material not only in an organisational function and for paraphrasing, but also in two short intrasentential switches reminiscent of Wenzel's c-elements, survives from as early as the end of the thirteenth century. In his analysis of this sermon, Fletcher particularly singles out these two instances of "[a]rbitrary macaronic usage«, though he sees this use as being "tentative ${ }^{38}{ }^{8}$ One of these two switches is the one after Quia in the last sentence under (14), Quia it ne es so foul macula in facie anime. In view of the much higher frequency of (mostly intersentential) English material with local function in this sermon, it seems, however, doubtful whether these two instances suffice to connect it to the so-called "macaronic sermons" of the late medieval period. As noted earlier, from a functional perspective, both elements with a local and those with a global function can be subsumed in a single theoretical and descriptive framework.

(14) Sed in quibus, putas, stat Christi cultus? In riche clopnge? In mangeries? [...] pis riche clopng es noht scarlet na velvet, bot a serk of chastite and a kirtil of humilite, [...] Primum, quia iocale pulcrum non ponitur in fimario sed in forceario. [...] Quartum, quia magister non admittit discipulum qui eius non vult suscipere documentum. [...] pis proud tiffynge nes na crokettes na shavinge quantum ad homines, na lokettes na smeringe quantum ad mulieres, sed sunt hertly compunccioun, clenli confessioun, [...] Quia it ne es so foul macula in facie anime, quin ista non alluant, nec ita parvus capillus in capite, quin ista ad suum locum non dirigant. ${ }^{39}$

35 Fletcher, »Benedictus«, 230. For late medieval English sermons, see also Spencer, English Preaching, and especially O'Mara and Paul, Repertorium. For late medieval Latin sermon collections, see Wenzel, Latin Sermon Collections.

36 See Wenzel, Macaronic Sermons, 5-6. Notetaking by reporters (»reportatores«) and translation play some role in writing down orally delivered medieval sermons, but the majority of sermon texts are conscious products of the authors, often serving as reading matter and models for other preachers (Fletcher, Popular Preaching, 12-14).

37 Wenzel, Macaronic Sermons, Q-38-108, 16. Transl. H.S., with comment by anonymous reviewer.

38 Fletcher, Popular Preaching, 64. The sermon was first edited in Fletcher, "Benedictus«, followed by an interesting discussion of the "macaronic style« in medieval England, with examples of mixed-language texts from various text types. Fletcher briefly points to some similarities between the "macaronic style« and modern spoken code-switching. A revised version of his paper forms the basis of chapter 3 in Fletcher, Popular Preaching, 33-66, which already incorporates some insights from historical code-switching research and provides detailed discussions of some non-religious bilingual texts, without, however, giving up the vague concept of »macaronic«.

39 Fletcher, "Benedictus«, 224-225. I would like to thank Dr. Reinhold Peterwagner for his translation of the Latin passages and an anonymous reviewer for a clarification of the last sentence. 
(But wherein, do you think, is the veneration of Christ manifest? In rich clothing? In feasting? [...] This rich clothing is not scarlet nor velvet, but a shirt of chastity and a coat of humility, [...] Firstly, one does not put beautiful jewellery on the dunghill, but into a box. [...] Fourthly, because the teacher does not admit a pupil who does not accept his teaching. [...] This proud finery is neither curls nor shaving with men, neither lovelocks nor ointment with women, but they are genuine repentance, honest confession, [...] Because there is no blemish on the soul's countenance so foul that these do not cleanse [it], nor a hair on the head so short that these do not put [it] in its proper place.)

The section Code-Switching in Old English Texts has illustrated that bilingual texts which would fit Wenzel's narrow definition of macaronic are already attested in the Old English period, see the charter in example (7). In the rest of this section, we will show that also in the heyday of "macaronic " sermons, that is between the middle of the fourteenth and the middle of the fifteenth century, ${ }^{40}$ a large number of multilingual texts were produced in different text types, many of them also containing intrasentential switches with global functions. In a period in which part of the educated literate elite was bi- or trilingual, many people would be more or less regularly confronted with various multilingual texts and text types, both literary and non-literary. Among the latter are a range of administrative texts (Year books, wills, business accounts), scientific and medical texts, letters and various religious texts. ${ }^{41}$ The professional multilingual scribes of the period regularly produced and copied not only monolingual texts in Latin, Anglo-Norman and English, but also numerous mixed-language texts. ${ }^{42}$ The following brief survey will start with two types of administrative texts, namely Year books and wills.

In the so-called Year books, late medieval legal reports, code-switching is frequently used from an early time onwards, especially in an organisational function, namely to »differentiate types of information in an entry « ${ }^{43}$. In the early fourteenth-century passage under (15), the report on the legal case is in French, while Latin is used to comment on it (mirum tamen fuit, etc.). ${ }^{44}$

(15) E eide ne fut pas graunté en ceo cas par Berr. Mirum tamen fuit. mes dyt luy fut qe il alast a son bref de convenaunt ou a son bref de mesne lequel qe il voloit etc. cuius contrarium videtur etc.

(And aid was not granted in this case by Bereford, [which] was strange nevertheless. But he was told to have recourse to his writ of covenant or of mesne, whichever he wished etc. Of which the contrary seems etc.)

40 Wenzel, Macaronic Sermons, 13.

41 See Schendl and Wright, Code-Switching in Early English, 22.

42 Schendl and Wright, Code-Switching in Early English, 21.

43 See Davidson, Discourse features, 344.

44 The passage under (15) from the Year Books Edward II, 1316-1317 is discussed in some detail in Davidson, Discourse features, 346-347, from where the example and translation are taken; see also Schendl, Language contact, 20-21. An example of code-switching between French and Latin in the Year books of 1470 is discussed in Fletcher, Popular Preaching, 55-56 as an instance of "macaronic« usage. 
A typical passage from a bilingual will from 1400 is given under (16), with Latin as the dominant language and frequent switches into English, mainly single words and short phrases referring to bequeathed objects (platyngborde, brade bordes beste, etc.); however, such objects are frequently also referred to in Latin, such as duo par forpicarum (two pairs of tongs), etc., a strategy already familiar from the Old English charter under (7) above. The short switches into English have no specific local function but rather a global one, since they reflect the jargon of lawyers, that is, of a particular community of practice. ${ }^{45}$

(16) Lego Willielmo Thorneton, servo meo, duo par forpicarum, \& duas mensas pro cessurâ panni, \& unum platyngborde, cum uno strayte [...] \& vj mostir bordes \& vj brade bordes beste in domo. ${ }^{46}$

(I leave to my servant William Thornton, two pairs of tongs, and two boards for the cutting of cloth, and one folding board, with one (table) cloth [...] and vj pattern-boards and vj broad boards best in the house.)

The numerous administrative mixed-language documents from medieval England have been described and analysed in a number of papers by Laura Wright. ${ }^{47}$ Their extensive use of a complex system of abbreviation and suspension marks creates numerous visual diamorphs which cannot be classified for a specific language ${ }^{48}$ For the readers of such documents, the language-neutral abbreviations and suspensions clearly facilitated the reading of the text, since they did not have to know the inflexional and derivational suffixes of the three languages frequently mixed in these documents, Latin, French and English. This mixed-language code also follows specific rules which, in general, do not occur in other multilingual text types from the period.

An exception to this text type-specific restriction of this mixed-language code is, however, found in William Worcester's Itineraries. These are a collection of informal travel notes written during his journeys through the south of England and Wales in the late 1470s. They show a mixture of medieval Latin with English and some French, with many of the typical features of the administrative mixed-language code, with which Worcester was familiar from his long professional experience. Some of these features occur in the passage under (17), such as the use of the originally French article le $(z)$ or $l a$ to indicate a switch into English, the occurrence of visual diamorphs and the consistent variation between languages.

45 For the relevance of the concept of community of practice in historical linguistics, see Kopaczyk and Jucker, Communities of Practice.

46 Raine, Testamenta Eboracensia, 260; transl. H.S.

47 See, for example, Wright, Pilot study; Wright, On variation. A short summary of the main features of this "mixed-language code« is given in Wright, Pilot study, 131. Since the system of abbreviations and suspensions used in the manuscripts is highly complex, no illustrative example will be quoted here. The reader is referred to the original publications for illustration and further details.

48 For the concept of "visual diamorph «, see Wright, On variation, 203. Cases in point are the preposition in in the mixed phrase beste in domo (example 16) as well as the forms serpentes and cormorantes in (17), where -es can be interpreted as either the Latin or the English plural suffix. 
(17) Insula Prestholm proxima jnsula Angelsey per dimidium miliaris de Anglesey [...] et ibi crescent cuniculi et serpentes addyrs snakes gullys mewys cormorantes, et arbores vocate elders. [...] non est populata distat a le maynlond circa spacium duorum arcuum vocat. bowshottys Et est ibi vnum bay pro nauibus saluandis in le northsyde jnsule vocatum le Rounde Table. ${ }^{49}$

(The island of Priestholm is close to Anglesey, half a mile from Anglesey, [...] and there live rabbits and serpents, adders, snakes, gulls, mews, cormorants, and trees called elders. [...] It is not inhabited. It lies from the mainland at a distance of about two bowshots called bowshots. And there is a bay for the safe riding of ships on the north side of the island called the Round Table.)

The passage under (18) is from a much-quoted French-English bilingual letter sent by the Dean of Hereford to King Henry IV in 1403, asking for help against the Welsh insurgents. The opening part and the objective factual report are in French, which is clearly the dominating language of the letter, while the following switches into English express a more personal and urgent plead. The same occurs again in the concluding passage, where the author first switches back to French and then again into English. The switches into English expressing urgency and personal involvement have an indexical function..$^{50}$

(18) Qar, mon tresredoute Seigneur, vous trouverez pour certein que si vous ne venez en vostre propre persone pour attendre [apres] voz rebelx en Galys, vous ne trouverez un gentil que veot attendre deinz vostre dit Countee. Warfore, for Goddesake, thinketh on zour beste Frende, God, and thanke Hym [...]; and leveth nought that ze ne come for no man that may counsaille zowe the contrarie; [...] Jeo prie a la Benoit Trinite que vous ottroie bone vie ove tresentier sauntee a treslonge durre, and sende zowe sone to ows in help and prosperitee; for, in god fey, I hope to Al Mighty God that [...] ze schulle have the victorie of alle zoure enemyes. [...] Escript a Hereford, en tresgraunte haste,

(For, my most dread Lord, you will find for certain that, if you do not come in your own person to await your rebels in Wales, you will not find a single gentleman that will stop in your said county. Wherefore, for God's sake, think on your best friend, God, and thank Him, [...] and leave nought that you do not come for no man that may counsel you the contrary; [...] I pray the Blessed Trinity to give you good life, with most complete good health, very long to endure, and send you soon to us in help and prosperity; for, in good faith, I hope to Almighty God, that [...] you shall have the victory of all your enemies. [...] Written at Hereford, in very great haste,)

49 William Worcester, Itineraries, ed. Harvey, 134-136, from where the example and translation are taken. For a fuller discussion of Worcester's use of the administrative mixed code in his travel notes, see Schendl, William Worcester, 321-322, where this example is printed with the complex abbreviations of the manuscript CCCC MS 210.

50 The passage under (18) is quoted from Schendl, Code-choice and code-switching, 254-258, where an analysis of the text with translation is provided. See also the discussion in Schendl, Language contact, 21. 
More frequent are letters switching between English and Latin, especially from the later fifteenth century onwards. Well-known examples are those written by Friar John Brackley to members of the Paston family, in a number of which he extensively switches between English and Latin. While many of Brackley's switches have local functions, there are also quite a number which, in Fletcher's view, show a "macaronic style [...] most comparable to the apparently random macaronic prose alternation « of sermons. ${ }^{51}$

Medieval medical texts are a rich source of code-switches in different organisational functions, including metalinguistic comments on the efficacy of the remedy as in (19) and for structural reasons, though a local function is not always evident: ${ }^{52}$

(19) seth ij littill bundell of anece in wyne [...] and lay abowt the navyl et sanabitur ${ }^{53}$ (boil two small bundles of anise in wine [...] and lay unto the navel and [it] will be healed)

(20) tak alym water and put perynne pyn parchemen ut aqua sit tepidus and let hit drinke ${ }^{54}$

(take alum water and put your parchment into it so that the water becomes warm and let (them) drink it)

Though Middle English code-switching clearly predominates in non-literary text types, there are also numerous examples in literary texts, such as drama and poetry. ${ }^{55}$ Different from the Old English poem illustrated under (10) above, the following mid-fifteenth-century English-Latin poem illustrates that poetical code-switching is not always linked to metrical form, but may be quite irregular and intrasentential, not always having a local function.

(21) Regnum Anglorum regnum Dei est, As the Aungelle to seynt Edward dede wyttenesse.

Now regnum Sathane, it semethe, reputat best.

For filii scelerati haue broughte it in dystresse. ${ }^{56}$

(The kingdom of the angels/English is the kingdom of God,

As the angel said to St Edward.

Now the kingdom of Satan, it seems, accounts best.

For the accursed sons have brought it in distress.)

51 See Fletcher, Popular Preaching, 52.

52 See e.g. Voigts, What's the word?, with a discussion of different functions.

53 Recipes, quoted from Pahta, Code-switching in medical texts, 201. Transl. H.S.

54 From an "alchemical process« in MS Bodley 177, fol. 18v, quoted from Voigts, What's the word?, 819. Transl. H.S.

55 For code-switching in medieval English literature in general, see Schendl, Code-switching in early English literature, which also looks at syntactic aspects of early switching. For multilingual medieval drama, see Diller, Code-switching in drama.

56 See Schendl, »To London from Kent«, 60, where this passage from the Gates of Canterbury is quoted and discussed. Transl. H.S. 
Piers Plowman, an important late Middle English religious verse piece, is known for its great number of Latin passages, mainly biblical quotations, which are, in general, fully integrated into the English text, see (22) where the switches into Latin are biblical quotations slightly adapted by the author to fit his argument. The numerous intrasentential short switches in particular, as in (23), do not always have a clear local function and thus resemble Wenzel's "macaronic elements«. ${ }^{77}$

(22) Preyeres of a parfit man and penaunce discret Is the leuest labour pat oure lord pleseth.

Non de solo, y sayde, for sothe viuit homo,

Nec in pane et in pabulo, the pater-noster wittenesseth;

Fiat voluntas dei - pat fynt vs alle thynges. ${ }^{58}$

(Prayers of a perfect man and judicious penance

Is the most precious work that pleases our Lord.

Not from the soil I said, in truth doth man live,

nor in bread and in food; the Lord's Prayer witnesses,

Let God's will be done, who provides us with everything.)

(23) The comune clamat cotidie, vch a man to oper

(the common people cries out daily, each man to the other). ${ }^{59}$

The examples in the preceding sections have illustrated that language mixing is a frequent phenomenon in a range of text types from medieval England. It can serve various functions and occurs in texts with different levels of formality, from poetic texts and well-organised sermons to letters and private travel notes. What they all have in common is that they have come down to us in written form, while code-switching in modern languages is predominantly found in speech, though increasingly also appears in written form in e-mails and the so-called social media (e.g. twitter and facebook).

\section{Medieval Code-Switching - Spoken or Written Phenomenon?}

The question whether medieval written code-switching is linked to multilingual speech or only a phenomenon of writing has been repeatedly addressed. ${ }^{60}$ In the introduction it was said that medieval code-switching would be regarded as a written phenomenon, since we do not have direct access to earlier spoken multilingual data. But it is most likely that in certain contexts multilingual texts would have been presented in oral form more or less identical to their written format. This could be the case with the homiletic type of sermon, where Latin biblical quotations are followed by a vernacular translation and which is evidently intended to be delivered in this form (see the discussion of examples 2 and 3 above). But there is also some evidence that late medieval preachers sometimes used Latin elements in their

57 A detailed discussion of code-switching in Piers Plowman is found in Machan, Language contact, and in Davidson, Language-Mixing, 122-176.

58 William Langland, Piers Plowman, C.5.84-87, 101. Transl. H.S.

59 William Langland, Piers Plowman, C.21.416, 358. Transl. H.S.

60 See e.g. Gardner-Chloros, Historical and modern studies; Schendl and Wright, Code-Switching in Early English, 27-28. 
vernacular sermons. ${ }^{61}$ As for charters, the handing over of a lease in Old English times used to be linked to an oral act to become legally binding, though this would hardly have been in the form reflected in the lease under (7), where the objects and services concerned are variously in Latin and in English, and this applies to some extent also to the bilingual wills illustrated under (16). There may be reflections of speech in certain types of multilingual administrative texts, ${ }^{62}$ but these at best provide indirect evidence for spoken code-switching. The reading aloud of texts to other individuals or larger audiences, both literary and non-literary, was certainly more widespread in medieval times, and mixed-language texts such as letters, poems or drama were certainly sometimes presented orally. But this involves the reproduction of written text and is very different from the spontaneous production of bilingual speech in direct verbal interaction. Other multilingual texts such as William Worcester's travel notes (see example 17) were personal notes hardly intended to be read to others.

More controversial is the question of the possible oral delivery of the so-called "macaronic sermons". With his claim that these may have been preached in their macaronic form, Wenzel renewed a dispute which had seemed to be settled for some time. ${ }^{63}$ His view was strongly criticised by Fletcher, who advanced convincing arguments for considering the "macaronic style« as a purely written phenomenon, linked to the changing status of Latin and English as written languages in late medieval England. ${ }^{64}$ Others, like Johnson claimed that it could hardly be decided "[w]hether the sermons were actually preached macaronically or only written down that way ${ }^{65}{ }^{6}$ The view of the present author corresponds in many points to that of Fletcher, considering "macaronic " sermons as a written phenomenon in a period of increasing vernacularisation of certain text types, which has been recognised as being often linked to an increase of code-switching. ${ }^{66} \mathrm{~A}$ further aspect may be a possible macro-level, global function of code-switching in such sermons, namely to establish or express group membership of an educated bilingual community of preachers and readers. ${ }^{67}$

61 See Kämmerer, Codeswitching in Predigten, 99-115, especially 108-112; Wenzel, Macaronic Sermons, 37, 47; Muessig, Vernacularization, 271-272.

62 See Ingham, Mixing languages.

63 Wenzel, Macaronic Sermons, 114-119.

64 Fletcher, Popular Preaching, 63-66.

65 Johnson, Grammar of Good Friday, xxii.

66 For the correlation between increasing vernacularisation and the increase of code-switching in certain historical text-types, see Schendl, Multilingualism, code-switching, and language contact, 524. Apart from sermons, this is also noticeable in letters and medical texts from medieval England. For the latter text type, see also Voigts, What's the word?, 814.

67 See Schendl, Late medieval macaronic sermons. 


\section{Conclusion}

The present paper has briefly sketched the development of the multilingual sermon in medieval England and has tried to show that these (including the so-called "macaronic" sermon) do not constitute a particularly unusual type of bilingual document. By presenting examples from a range of different text types with a variety of syntactic patterns and pragmatic functions of code-switching, it has been argued that all these multilingual documents should be seen as reflecting the written expression of general communicative strategies frequently used by multilingual speakers and writers over time and in different domains. This also means that the medieval multilingual sermon is well embedded in a much wider context of societal multilingualism reflected in these multilingual texts and text types. It also shows that intrasentential switches, often with a global function, are not restricted to sermons, but are frequent in other text types as well, starting as early as the Anglo-Saxon charters. Such texts may seem to be a "curious linguistic phenomenon « for the modern reader, but they were most likely not so for literate medieval people. Though most specific text types had their own professional or literary conventions which influenced the patterns and functions of code-switching and partly changed over time, they all represent the same communicative strategies of multilingual language users, which links these texts to modern code-switching, spoken and written. 


\section{References}

Auer, Peter, From codeswitching via language mixing to fused lects: Toward a dynamic typology of bilingual speech, The International Journal of Bilingualism 3 (1999) 309-332.

Bériou, Nicole, Les sermons latins après 1200, in: Beverly M. Kienzle (ed.), The Sermon (Turnhout, 2000) 363-447.

Conti, Aidan, The circulation of the Old English homily in the twelfth century: New evidence from Oxford, Bodleian Library, MS Bodley 343, in: Aaron J. Kleist (ed.), The Old English Homily: Precedent, Practice and Appropriation (Turnhout, 2007) 365-402.

Davidson, Mary C., Discourse features of code-switching in legal reports in late medieval English, in: Janne Skaffari, Matti Peikola, Ruth Carroll, Risto Hiltunen and Brita Wårvik (eds.), Opening Windows on Texts and Discourses of the Past (Amsterdam, 2005) 343-351.

Davidson, Mary C., Language-Mixing and Code-Switching in England in the Late Medieval Period. Unpublished PhD thesis (University of Toronto, 2001).

Diller, Hans-Jürgen, Code-switching in medieval English drama, Comparative Drama 31 (1997/1998) 500-537.

Fletcher, Alan J., »Benedictus qui venit in nomine Domini«: A thirteenth-century sermon for Advent and the macaronic style in England, Medieaeval Studies 56 (1994) 217-245.

Fletcher, Alan J., Late Medieval Popular Preaching in Britain and Ireland: Texts, Studies, and Interpretations, Sermo 5 (Turnhout, 2009).

Gardner-Chloros, Penelope, Code-Switching (Cambridge, 2009).

Gardner-Chloros, Penelope, Historical and modern studies of code-switching: A tale of mutual enrichment, in: Päivi Pahta, Janne Skaffari and Laura Wright (eds.), Multilingual Practices in Language History: English and Beyond, Language Contact and Bilingualism 15 (Berlin, 2018) 19-36.

Halmari, Helena and Timothy Regetz, Syntactic aspects of code-switching in Oxford, MS Bodley 649, in: Herbert Schendl and Laura Wright (eds.), Code-Switching in Early English (Berlin, 2011) 115-154.

Horner, Patrick J. (ed.), A Macaronic Sermon Collection from Late Medieval England: Oxford MS Bodley 649, Studies and Texts 153 (Toronto, 2006).

Ingham, Richard, Code-switching in the later medieval lay subsidy rolls, in: Herbert Schendl and Laura Wright (eds.), Code-Switching in Early English (Berlin, 2011) 95-114.

Ingham, Richard, Medieval bilingualism in England: On the rarity of vernacular code-switching, in: Päivi Pahta, Janne Skaffari and Laura Wright (eds.), Multilingual Practices in Language History: English and Beyond, Language Contact and Bilingualism 15 (Berlin, 2018) 319-337.

Ingham, Richard, Mixing languages on the Manor, Medium Avum 78 (2009) 80-97.

Johnson, Holly, The Grammar of Good Friday: Macaronic Sermons of Late Medieval England, Sermo 8 (Turnhout, 2012).

Kämmerer, Carmen, Codeswitching in Predigten des 15. Jahrhunderts, Studies in Eurolinguistics 4 (Berlin, 2006).

Kleist, Aaron J. (ed.), The Old English Homily: Precedent, Practice and Appropriation, Studies in the Early Middle Ages 17 (Turnhout, 2007).

Kopaczyk, Joanna and Andreas H. Jucker (eds.), Communities of Practice in the History of English, Pragmatics and Beyond New Series 235 (Amsterdam, 2013).

Machan, Tim W., Language contact in Piers Plowman, Speculum 69 (1994) 359-385. 
Matras, Yaron, Language Contact, Cambridge Textbooks in Linguistics (Cambridge, 2009).

Muessig, Carolyn, The vernacularization of late medieval sermons: Some French and Italian examples, in: Christopher Kleinhenz and Keith Busby (eds.), Medieval Multilingualism: The Francophone World and its Neighbours, Medieval Texts and Cultures of Northern Europe 20 (Turnhout, 2010) 267-284.

O'Mara, Veronica and Suzanne Paul, A Repertorium of Middle English Prose Sermons, 4 vols., Sermo 1 (Turnhout, 2007).

Pahta, Päivi, On structures of code-switching in medical texts from medieval England, Neuphilologische Mitteilungen 104 (2003) 197-210.

diPaolo Healey, Antonette, with John Price Wilkin and Xin Xiang, Dictionary of Old English Web Corpus (Toronto, 2009).

Raine, James (ed.), Testamenta Eboracensia or Wills Registered at York. Part I (London, 1836).

Schendl, Herbert, Beyond boundaries: Code-switching in the leases of Oswald of Worcester, in: Herbert Schendl and Laura Wright (eds.), Code-Switching in Early English (Berlin, 2011) 47-94.

Schendl, Herbert, Code-choice and code-switching in some early fifteenth-century letters, in: Peter J. Lucas and Angela M. Lucas (eds.), Middle English from Tongue to Text, Studies in English Medieval Language and Literature 4 (Frankfurt/Main, 2002) 247-262.

Schendl, Herbert, Code-switching in Anglo-Saxon England: A corpus-based approach, in: Päivi Pahta, Janne Skaffari and Laura Wright (eds.), Multilingual Practices in Language History: English and Beyond, Language Contact and Bilingualism 15 (Berlin, 2018) 39-59.

Schendl, Herbert, Code-switching in early English literature, Language and Literature 24 (2015) 233-248.

Schendl, Herbert, Code-switching in late medieval macaronic sermons, in: Judith A. Jefferson and Ad Putter (eds.), Multilingualism in Medieval Britain (c. 1066-1520): Sources and Analysis (Turnhout, 2013) 153-169.

Schendl, Herbert, Hec sunt prata to wassingwellan: Aspects of code-switching in Old English charters, Vienna English Working Papers 13 (2004) 52-68.

Schendl, Herbert, Language contact and code-switching in multilingual medieval England, in: Juan Camilo Conde-Silvestre and Javier Calle-Martin (eds.), Approaches to Middle English: Variation, Contact and Change, Studies in English Medieval Language and Literature 47 (Frankfurt/Main, 2015) 15-34.

Schendl, Herbert, »To London from Kent / Sunt predia depopulantes«: Code-switching and medieval English macaronic poems, Vienna English Working Papers 6 (1997) 52-66.

Schendl, Herbert, Multilingualism, code-switching, and language contact in historical sociolinguistics, in: Juan Manuel Hernández-Compoy and Juan Camilo Conde-Silvestre (eds.), The Handbook of Historical Sociolinguistics (Malden, MA, 2012) 520-533.

Schendl, Herbert, Syntactic constraints on code-switching in medieval texts, in: Irma Taavitsainen, Terttu Nevalainen, Päivi Pahta, and Matti Rissanen (eds.), Placing Middle English in Context (Berlin, 2000) 67-86.

Schendl, Herbert, William Worcester's Itineraria: Mixed-language notes of a medieval traveller, in: Laura Wright (ed.), The Multilingual Origins of Standard English, Topics in English Linguistics 107 (Berlin, 2020) 317-341.

Schendl, Herbert and Laura Wright (eds.), Code-Switching in Early English, Topics in English Linguistics 76 (Berlin, 2011).

Spencer, H. Leith, English Preaching in the Late Middle Ages (Oxford, 1993). 
Swan, Mary, Preaching past the conquest: Lambeth Palace 487 and Cotton Vespasian A. XXII, in: Aaron J. Kleist (ed.), The Old English Homily: Precedent, Practice and Appropriation (Turnhout, 2007) 403-423.

Thomason, Sarah G., Language Contact (Edinburgh, 2001).

Timofeeva, Olga, Anglo-Latin bilingualism before 1066: Prospects and limitations, in: Alaric Hall, Olga Timofeeva, Ágnes Kiricsi and Bethany Fox (eds.), Interfaces between Language and Culture in Medieval England: A Festschrift for Matti Kilpiö (Leiden, 2010) 1-36.

Voigts, Linda E., What's the word? Bilingualism in late-medieval England, Speculum 71 (1996) 813-826.

Wenzel, Siegfried, Latin Sermon Collections from Later Medieval England, Cambridge Studies in Medieval Literature 53 (Cambridge, 2005).

Wenzel, Siegfried, Macaronic Sermons: Bilingualism and Preaching in Late-medieval England, Recentiores: Later Latin Texts and Contexts (Ann Arbor, 1994).

William Langland, Piers Plowman: The C-Text, ed. Derek Pearsall (Exeter, 1994).

William Worcester, Itineraries, ed. John H. Harvey (London, 1969).

Wright, Laura, A pilot study on the singular definite articles $l e$ and $l a$ in fifteenth-century London mixed-language business writing, in: Richard Ingham (ed.), The Anglo-Norman Language and Its Contexts (Woodbridge, 2010) 130-142.

Wright, Laura, On variation in medieval mixed-language business writing, in: Herbert Schendl and Laura Wright (eds.), Code-Switching in Early English (Berlin, 2011) 191-218. 